\title{
Pemberian fortifikasi multi-mikronutrien berpengaruh terhadap pertumbuhan balita keluarga miskin
}

\section{Effect fortified multi micronutrient to growth of underfives of 6-59 month from poor communities}

Mursalim $^{1}$, Muhammad Juffrie ${ }^{2}$, Nenny Sri Mulyani²

\begin{abstract}
Background: Underfives from poor communities are susceptible group that will unlikely have sufficient nutrition (micronutrient) meanwhile this micronutrient is essential for growth. Some studies show the supplementation of micronutrient has good effects to child growth. Therefore it is necessary to study the supply of fortified multi-micronutrient and its effect to growth of underfives from poor communities.

Objective: To identify the supply of fortified multi micronutrient and its effect to growth of underfives of 6-59 months from poor communities.

Method: The study was a pre-experiment that used a group pre test-post test design. Subject were underfives of 6-59 months from poor communities that got fortified multi micronutrient. The intervention of fortified multi micronutrient supply was given once a week (1 sachet/day) within 4 months. Data of family characteristics and identity of the subject were collected at the beginning of the study. Measurement of physical weight and height/length, consumption recall, collection of data on disease infection (acute respiratory tract and diarrhea) were carried out at the beginning and end of the study.

Results: The result of statistics test showed there was significant increase $(p<0.05)$ in weight, height/length and nutrition status (z-score) to index of weight for height/length, height for age, and that there was significant descent to acute respiratory tract infection and diarrhea of underfives of 6-59 months from poor communities after the supply of fortified micronutrient containing vitamin A, B1, B2, B3, B6, B12, folate acid, vitamin C, D3, E, Fe and zink.

Conclusion: The supply of fortified multi micronutrient could increase weight, height/length and nutrition status (z-score), index of weight for height/length and index of weight for age and decreased of acute respiratory tract infection and diarrhea disease in underfives of 6-59 months from poor communities.
\end{abstract}

KEY WORDS fortified multi micronutrient, growth of underfives, nutrient intake, infectious disease (acute respiratory tract infection and diarrhea)

\begin{abstract}
ABSTRAK
Latar belakang: Balita keluarga miskin merupakan kelompok rawan yang cenderung mendapat makanan yang tidak memenuhi kecukupan gizi (mikronutrien) sesuai kebutuhan, sehingga akan mengganggu proses pertumbuhan. Beberapa penelitian menyatakan bahwa suplementasi mikronutrien memberi pengaruh positif terhadap pertumbuhan balita. Oleh karena itu perlu dilakukan penelitian tentang pemberian multi-mikronutrien fortifikasi dan pengaruhnya terhadap pertumbuhan balita keluarga miskin.

Tujuan: Untuk mengetahui pemberian multi-mikronutrien fortifikasi dan pengaruhnya terhadap pertumbuhan balita keluarga miskin usia 6-59 bulan.

Metode: Jenis penelitian ini adalah pre-experiment dengan rancangan one group pre test - post test design. Subjek penelitian adalah balita keluarga miskin usia 6-59 bulan yang mendapat multi-mikronutrien fortifikasi. Pemberian multimikronutrien fortifikasi dilakukan seminggu sekali (1 sachet/hari) berlangsung selama 4 bulan. Pengumpulan data karakteristik keluarga dan identitas subyek dilakukan pada awal penelitian. Pengukuran berat badan dan tinggi/panjang badan, recall konsumsi, data penyakit infeksi (ISPA dan diare), dilakukan pada awal dan akhir penelitian.

Hasil: Berdasarkan uji statistik terdapat peningkatan yang bermakna $(p<0,05)$ pada berat badan, tinggi/panjang badan, dan status gizi (nilai z-skor) menurut indeks $B B / T B(P B), B B / U$, dan adanya penurunan yang bermakna terhadap penyakit ISPA dan diare pada balita keluarga miskin usia 6-59 bulan setelah diberikan multi-mikronutrien fortifikasi yang mengandung vitamin A, B1, B2, B3, B6, B12, asam folat, vitamin C, D3, E, Fe, dan Zn.

Kesimpulan: Pemberian multi-mikronutrien fortifikasi dapat meningkatkan berat badan, tinggi/panjang badan, dan status gizi (nilai z-skor) menurut indeks BB/TB(PB) dan BB/U serta menurunkan penyakit ISPA dan diare pada balita keluarga miskin usia 6-59 bulan.
\end{abstract}

KATA KUNCI: multi-mikronutrien fortifikasi, pertumbuhan balita, asupan zat gizi, penyakit infeksi (ISPA dan diare)

\footnotetext{
1. Direktorat Bina Gizi, Kementerian Kesehatan RI, Jl. HR Rasuna Said Blok X5 Kav 4-9 Jakarta Selatan, email: mursalim.urip@gmail.com

2. Instalasi Kesehatan Anak RSUP Dr. Sardjito, Jl. Kesehatan, Yogyakarta 55281, e-mail: juffrie@indosat.net.id

3. Instalasi Kesehatan Anak RSUP Dr. Sardjito, Jl. Kesehatan, Yogyakarta 55281
} 


\section{PENDAHULUAN}

Status gizi anak balita di Indonesia hingga saat ini masih memprihatinkan. Berdasarkan survei kesehatan nasional (Susenas) tahun 2002, masih terdapat 27,3\% atau sekitar 5 juta anak balita menderita gizi kurang dan $8 \%$ atau sekitar 1,3 juta di antaranya mengalami gizi buruk. Keadaan ini merupakan ancaman bagi upaya peningkatan kualitas sumberdaya manusia Indonesia, karena kurang energi protein erat kaitannya dengan gagal tumbuh kembang anak balita termasuk rendahnya tingkat kecerdasan (1). Data Susenas tahun 2005 menunjukkan bahwa prevalensi gizi kurang meningkat menjadi $28 \%$ dan $8,8 \%$ di antaranya mengalami gizi buruk. Prevalensi gizi kurang dan gizi buruk yang cukup tinggi ditemukan pada anak balita usia 6-23 bulan di perkotaan maupun di pedesaan (2).

Gagal tumbuh atau growth faltering merupakan suatu kejadian yang ditemui pada hampir setiap anak Indonesia. Rata-rata anak Indonesia lahir dengan berat badan dan panjang badan normal. Kegagalan pertumbuhan yang nyata mulai terlihat sejak anak berusia 4 bulan. Gagal tumbuh pada dasarnya merupakan ketidakmampuan anak untuk mencapai berat badan atau tinggi badan sesuai jalur pertumbuhan (3).

Pada tahun 2006, tingkat kemiskinan di Indonesia mencapai $17,8 \%$ atau sekitar 40 juta jiwa penduduk yang masih berada di bawah garis kemiskinan. Beberapa faktor penyebab masalah gizi salah satunya adalah kemiskinan yang dinilai memiliki peranan penting dan bersifat timbal balik, artinya kemiskinan akan menyebabkan kurang gizi dan kurang gizi akan melahirkan kemiskinan (4). Kemampuan keluarga yang rendah untuk menyediakan makanan berkualitas dan sesuai kebutuhan akibat dari kemiskinan, akan menyebabkan rendahnya asupan gizi, sehingga anak cenderung mengalami gangguan pertumbuhan dan perkembangan (1). Kekurangan zat gizi mikro sebagai bagian dari kekurangan zat gizi, kini telah berkembang menjadi masalah kesehatan masyarakat di Indonesia dan diperkirakan penduduk yang mempunyai risiko menderita kekurangan zat gizi mikro dapat mencapai lebih dari $70 \%(5)$.

Kecenderungan tersebut berkorelasi pula dengan rendahnya kualitas makanan yang dikonsumsi dalam keluarga, dan rendahnya kualitas makanan pendamping air susu ibu (MP-ASI) lokal untuk balita di bawah 24 bulan. MP-ASI seharusnya terdiri dari zat gizi yang mencukupi, aman bagi kesehatan, dan harganya terjangkau oleh keluarga miskin.

Pemberian multi-mikronutrien fortifikasi dalam bentuk springkel merupakan salah satu langkah yang dapat dilakukan dalam upaya meningkatkan mutu gizi makanan balita keluarga miskin untuk pertumbuhan yang optimal. Beberapa penelitian menunjukkan bahwa mikronutrien memberikan pengaruh positif terhadap pertumbuhan balita. Oleh karena itu perlu dilakukan penelitian tentang pemberian multi-mikronutrien fortifikasi pada balita, yang bertujuan untuk mengetahui asupan multi-mikronutrien fortifikasi dan pengaruhnya terhadap pertumbuhan balita keluarga miskin usia 6-59 bulan di Kota Jakarta Utara.

\section{BAHAN DAN METODE}

Jenis penelitian yang dilakukan adalah preexperiment dengan rancangan one group pretestposttest design. Populasi penelitian adalah balita usia 6-59 bulan yang berdomisili dan tercatat sebagai warga yang menerima multi-mikronutrien fortifikasi pada tiga kecamatan di wilayah Kota Jakarta Utara dengan jumlah 5.414 balita. Subjek penelitian adalah balita usia 6-55 bulan yang memenuhi kriteria inklusi. Kriteria inklusi yaitu: balita usia 6-55 bulan berasal dari keluarga miskin, terdaftar atau tercatat sebagai warga di wilayah penelitian, menerima multi-mikronutrien fortifikasi selama penelitian, bersedia menjadi subjek penelitian dengan persetujuan tertulis (written informed consent) dari orang tua. Kriteria eksklusi yaitu: menderita penyakit kronis dan berbahaya berdasarkan diagnosis dokter, menderita kelainan bawaan yang dapat mengganggu proses pertumbuhan balita.

Besar subjek penelitian diperoleh menggunakan rumus rata-rata satu populasi (6) dengan tingkat kepercayaan $95 \%(\alpha=1,96)$, kekuatan uji $90 \%(\beta=1,28)$, simpangan baku $(\sigma) z$-skor BB/TB pada anak normal sebesar 0,99 , selisih rata-rata z-skor BB/TB pada satu kelompok berpasangan (pre-post) yang diharapkan sebesar 0,17 . Sehingga perkiraan jumlah subjek minimal yang diperlukan sebesar 356 balita. Untuk mengantisipasi subjek yang drop out sebesar $10 \%$, maka jumlah balita yang diperlukan sebagai subjek penelitian sebesar 396 balita. Jumlah subjek yang terpilih secara random (acak sederhana) dan memenuhi kriteria serta mengikuti sampai akhir penelitian sebanyak 386 balita.

Penelitian dilakukan di wilayah Kecamatan Penjaringan, Kecamatan Koja, dan Kecamatan Cilincing. Pemilihan lokasi penelitian berdasarkan kebutuhan akan informasi masalah gizi yang terjadi di masyarakat, merupakan tiga kecamatan dari enam kecamatan terpadat dengan jumlah balita paling banyak yang berasal dari keluarga miskin, prevalensi kurang gizi cukup tinggi, dan merupakan kantong-kantong kemiskinan yang belum disentuh oleh penelitian yang serupa. Penelitian dilaksanakan pada bulan November 2008 sampai dengan Maret 2009. Selama penelitian subjek akan diberikan multimikronutrien fortifikasi dalam bentuk springkel selama 4 bulan. Perlakuan kepada subjek dilakukan setiap hari selama penelitian, observasi dan pengukuran dilakukan pada awal dan akhir penelitian. 
Variabel dalam penelitian ini meliputi variabel tergantung yaitu: berat badan, tinggi badan atau panjang badan, status gizi (nilai z-skor), dan penyakit infeksi (ISPA dan diare); variabel bebas yaitu: multi-mikronutrien fortifikasi; dan variabel pengganggu yaitu asupan zat gizi.

Multi-mikronutrien fortifikasi (MMF) adalah mikronutrien dalam bentuk springkel dengan komposisi per satu gram mengandung: vitamin A (Retinyl acetate) $417 \mathrm{mcg}$; vitamin B1 (Thiamine mononitrate) 0,5 mg; vitamin B2 (Riboflavin) 0,5 mg; vitamin B3 (Niacinamide) $5 \mathrm{mg}$; vitamin B6 (Pyridoxine HCL) $0,5 \mathrm{mg}$; vitamin B12 (Cyanocobalamin) $1 \mathrm{mcg}$; asam folat (Folic acid) $150 \mathrm{mcg}$; vitamin C (Ascorbic acid) $30 \mathrm{mg}$; vitamin D3 (Cholecalciferol) $5 \mathrm{mcg}$; vitamin E (Alpha-tocopherol acetate) $6 \mathrm{mg}$; Fe (Ferro fumarate) $10 \mathrm{mg}$; dan Zn (Zink gluconate) $5 \mathrm{mg}$ dengan filler maltodextrin, sebagai tambahan vitamin dan mineral pada makanan balita 6-59 bulan yang siap dimakan. Asupan multi-mikronutrien fortifikasi adalah proporsi atau jumlah multi-mikronutrien fortifikasi (dalam satuan sachet) yang dikonsumsi bersama makanan lain setiap hari sampai akhir penelitian oleh balita keluarga miskin usia 6-59 bulan.

Status gizi ditentukan melalui pengukuran antropometri dengan indeks berat badan menurut umur $(B B / U)$, berat badan menurut tinggi badan atau panjang badan (BB/TB atau BB/PB), dan tinggi badan atau panjang badan menurut umur ( $T B / U$ atau $P B / U$ ), yang diukur adalah status gizi (nilai z-skor) awal dan status gizi (nilai z-skor) akhir. Berat badan $(\mathrm{kg})$ diukur dengan menggunakan timbangan dacin dengan ketelitian $0,1 \mathrm{~kg}$. Panjang badan $(\mathrm{cm})$ diukur pada balita usia 6-24 bulan dalam posisi berbaring atau telentang menggunakan alat ukur panjang badan dengan ketelitian $0,1 \mathrm{~cm}$, sedangkan pengukuran tinggi badan $(\mathrm{cm})$ dilakukan pada balita usia lebih dari 24-59 bulan dalam posisi berdiri menggunakan microtoice dengan ketelitian $0,1 \mathrm{~cm}$.

Indikator status gizi dikategorikan berdasarkan sistem Indonesia rujukan WHO (7) dalam menilai status gizi balita yaitu: kategori indikator berat badan menurut umur (BB/U) adalah gizi lebih bila z-skor >+2SD, gizi baik bila z-skor -2SD sampai +2SD, gizi kurang bila z-skor -3SD sampai <-2SD, dan gizi buruk bila z-skor <-3SD; kategori indikator berat badan menurut tinggi atau panjang badan ( $\mathrm{BB} / \mathrm{TB}$ atau $\mathrm{BB} / \mathrm{PB}$ ) adalah sangat kurus bila z-skor <-3SD, kurus bila z-skor -3SD sampai <-2SD, normal bila z-skor -2SD sampai +2SD, gemuk bila z-skor >+2SD; kategori indikator tinggi badan atau panjang badan menurut umur (TB/U atau PB/U) adalah normal bila z-skor $\geq-2 S D$, pendek bila z-skor -3SD sampai <-2SD, sangat pendek bila z-skor $<-3 S D$. Indikator panjang badan menurut umur $(\mathrm{PB} / \mathrm{U})$ dan berat badan menurut panjang badan (BB/PB) digunakan untuk balita usia di bawah 24 bulan, sedangkan indikator BB/TB dan TB/U digunakan untuk balita 24 bulan sampai 59 bulan.
Keluarga miskin adalah keluarga yang tercatat sebagai keluarga miskin berdasarkan data yang dikeluarkan oleh wilayah setempat, atau telah terpenuhinya minimal tiga dari beberapa kriteria berikut yaitu: tidak mempunyai pekerjaan tetap atau sumber pendapatan utama di bawah upah minimum regional (UMR) per bulan, luas lantai tempat tinggal kurang dari $8 \mathrm{~m}^{2}$ per orang, jenis lantai bangunan tempat tinggal terluas adalah tanah, hanya mampu membeli pakaian satu kali dalam satu tahun, tingkat pendidikan kepala keluarga hanya sampai $\mathrm{SD}$, tidak mampu berobat ke puskesmas dengan biaya sendiri, serta keluarga hanya mampu memenuhi satu atau dua kali makan dalam sehari untuk setiap anggota keluarga.

ISPA (Infeksi Saluran Pernapasan Akut) adalah penyakit infeksi saluran pernafasan yang dapat berlangsung sampai 14 hari, ditandai dengan gejala seperti batuk atau pilek dengan atau tanpa demam. Insiden ISPA adalah berapa kali terserang ISPA (frekuensi kambuh) selama penelitian. Kasus dinyatakan sebagai insiden baru jika jarak antara kesembuhan sebelumnya dengan kasus baru minimal $2 \times 24$ jam. Diare adalah suatu penyakit yang ditandai dengan perubahan bentuk dan konsistensi tinja melembek sampai cair lebih dari 3 kali dalam 24 jam. Pada anak yang mendapat ASI, diare ditandai dengan perubahan bentuk dan konsisitensi tinja cair lebih dari 5 kali per hari. Diare bisa disertai muntah maupun adanya darah dan lendir dalam feses. Insiden diare adalah jumlah berapa kali anak terserang diare (frekuensi kambuh) selama penelitian. Diare dinyatakan sembuh bila frekuensi buang air besar cair atau lembek kurang dari tiga kali dalam 1x24 jam dan dinyatakan episode baru jika kasus terpisah dari insiden sebelumnya minimal 48 jam (2x24jam) tanpa diare.

Instrumen penelitian yang digunakan adalah form atau kuesioner data dasar untuk mengetahui karakteristik subjek, form recall untuk mengetahui asupan zat gizi balita dan asupan multi-mikronutrien fortifikasi, form pengukuran antropometri, dan alat ukur antropometri. Untuk keakuratan form atau kuesioner yang digunakan dalam pengumpulan data, terlebih dahulu dilakukan uji realibilitas dan validitas. Pengambilan data dilakukan oleh enumerator yang berpendidikan S1 atau D3 gizi dan kader posyandu yang sudah diberikan pelatihan standarisasi petugas lapangan.

Analisis statistik yang digunakan adalah proporsi rata-rata asupan multi-mikronutrien fortifikasi setelah perlakuan, uji beda berat badan, tinggi atau panjang badan, status gizi (nilai z-skor), asupan zat gizi, dan proporsi sakit, insiden, dan lamanya ISPA dan diare antara awal (pre-test) dan akhir penelitian (post-test) dengan paired $t$-test. Penelitian ini telah mendapatkan persetujuan dari Komite Etik Penelitian Kedokteran dan Kesehatan Fakultas Kedokteran Universitas Gadjah Mada. 


\section{HASIL}

\section{Karakteristik keluarga dan subjek penelitian}

Keluarga subjek adalah keluarga miskin dengan ratarata anggota keluarga sebanyak 5 orang, dan $64,61 \%$ dari total pengeluaran adalah untuk makan. Proporsi subjek berdasarkan jenis kelamin dan umur tidak jauh berbeda, dengan rata-rata berat badan $10,24 \mathrm{~kg}$ dan tinggi atau panjang badan $82,73 \mathrm{~cm}$ (Tabel 1).

Tabel 1. Karakteristik keluarga dan subjek penelitian

\begin{tabular}{|c|c|c|}
\hline Variabel & $\mathrm{n}(\%)$ & Rerata \pm SD \\
\hline \multicolumn{3}{|l|}{$\begin{array}{l}\text { Keluarga } \\
\text { Pendidikan ibu }\end{array}$} \\
\hline SLTA ke bawah & $313(81,09 \%)$ & - \\
\hline SLTA ke atas & $73(18,61 \%)$ & - \\
\hline $\begin{array}{l}\text { Jumlah anggota } \\
\text { keluarga }\end{array}$ & 386 & $5 \pm 2$ \\
\hline $\begin{array}{l}\text { Total pengeluaran } \\
\text { keluarga }\end{array}$ & 386 & $1.088 .681 \pm 487.258$ \\
\hline $\begin{array}{l}\text { Pengeluaran untuk } \\
\text { makan }\end{array}$ & 386 & $703.357 \pm 334.300$ \\
\hline \multicolumn{3}{|l|}{$\begin{array}{l}\text { Subjek } \\
\text { Jenis kelamin }\end{array}$} \\
\hline Laki-laki & $198(51,30 \%)$ & - \\
\hline Perempuan & $188(48,70 \%)$ & - \\
\hline \multicolumn{3}{|l|}{ Umur (bulan) } \\
\hline $6-24$ & $179(46,37 \%)$ & $15,69 \pm 5,12$ \\
\hline $25-55$ & $207(53,63 \%)$ & $37,30 \pm 8,38$ \\
\hline \multicolumn{3}{|l|}{ Indeks antropometri } \\
\hline $\begin{array}{l}\text { Berat badan }(\mathrm{kg}) \\
\text { Tinggi/panjang } \\
\text { badan }(\mathrm{cm})\end{array}$ & $\begin{array}{l}386 \\
386\end{array}$ & $\begin{array}{l}10,24 \pm 2,25 \\
82,73 \pm 9,34\end{array}$ \\
\hline
\end{tabular}

\section{Asupan multi-mikronutrien fortifikasi subjek}

Rata-rata proporsi asupan multi-mikronutrien fortifikasi sebanyak 80 sachet $(66,35 \%)$. Ada kecenderungan perbedaan asupan multi-mikronutrien fortifikasi pada subjek berdasarkan jenis kelamin dan umur subjek. Perbedaan proporsi rata-rata asupan multi-mikronutrien fortifikasi (MMF) subjek dapat dilihat pada Tabel 2.
Tabel 2. Proporsi asupan multi-mikronutrien fortifikasi subjek

\begin{tabular}{|c|c|c|}
\hline Subjek & $\mathrm{n}(\%)$ & Rerata \pm SD $(\%)$ \\
\hline $\begin{array}{l}\text { Total asupan MMF } \\
\text { Jenis kelamin }\end{array}$ & 386 & $66,35 \pm 25,26$ \\
\hline Laki-laki & $198(51,30 \%)$ & $67,05 \pm 24,35$ \\
\hline Perempuan & $188(48,70 \%)$ & $65,61 \pm 26,25$ \\
\hline Umur (bulan) & & \\
\hline $6-24$ & $179(46,37 \%)$ & $66,67 \pm 24,40$ \\
\hline $25-55$ & $207(53,63 \%)$ & $66,07 \pm 26,05$ \\
\hline $\begin{array}{c}\text { Status gizi (z-skor) } \\
\text { BB/TB(PB) }\end{array}$ & & \\
\hline Z-skor <-2SD & $57(14,77 \%)$ & $68,21 \pm 27,23$ \\
\hline Z-skor $\geq-2 S D$ & $329(85,23 \%)$ & $65,83 \pm 25,15$ \\
\hline $\mathrm{BB} / \mathrm{U}$ & & \\
\hline Z-skor <-2SD & $136(35,23 \%)$ & $66,57 \pm 22,27$ \\
\hline Z-skor $\geq-2 S D$ & $250(64,77 \%)$ & $66,22 \pm 26,80$ \\
\hline $\mathrm{TB}(\mathrm{PB}) / \mathrm{U}$ & & \\
\hline Z-skor <-2SD & $141(36,53 \%)$ & $65,51 \pm 23,92$ \\
\hline Z-skor $\geq-2 S D$ & $245(63,47 \%)$ & $66,83 \pm 26,05$ \\
\hline $\begin{aligned} \text { Keterangan }: \text { MMF } & : \\
\text { BB } & \vdots \\
\text { TB(PB) } & \vdots \\
& \text { SD }\end{aligned}$ & \multicolumn{2}{|c|}{$\begin{array}{l}\text { : multi-mikronutrien fortifikasi } \\
\text { : berat badan } \\
\text { : tinggi badan (panjang badan) } \\
: \text { umur } \\
: \text { standar deviasi }\end{array}$} \\
\hline
\end{tabular}

Berat badan, tinggi/panjang badan, dan status gizi (nilai z-skor) sebelum dan setelah perlakuan

Setelah mendapat asupan multi-mikronutrien fortifikasi selama 4 bulan dengan jumlah rata-rata sebanyak 80 sachet $(66,35 \%)$, terdapat peningkatan yang bermakna pada berat badan, tinggi/panjang badan, dan status gizi (nilai z-skor) (Tabel 3).

Rata-rata kenaikan berat badan dan tinggi badan merupakan besarnya daya ungkit dari mikronutrien yang diberikan kepada subjek selama 4 bulan. Bila dibandingkan dengan kenaikan berat badan dan tinggi badan minimal tanpa intervensi (standar) menurut kelompok umur yang sama dengan subjek penelitian, maka diperoleh besar peningkatan berat badan dan tinggi badan atau panjang badan serta daya ungkit multi-mikronutrien fortifikasi. Besarnya daya ungkit multi-mikronutrien fortifikasi terhadap pertumbuhan subjek tercermin dari adanya peningkatan berat badan dan tinggi atau panjang badan (Tabel 4).

Tabel 3. Berat badan, tinggi/panjang badan, dan status gizi (nilai z-skor) sebelum dan setelah perlakuan

\begin{tabular}{lcccc}
\hline \multicolumn{1}{c}{ Variabel } & Awal (Pre test) & Akhir (Post test) & Perbedaan & p \\
\hline Berat badan & $10,24 \pm 2,25$ & $11,19 \pm 2,38$ & $0,95 \pm 0,71$ & $<0,001^{*}$ \\
Tinggi/panjang badan & $82,73 \pm 9,34$ & $86,33 \pm 8,98$ & $3,61 \pm 1,63$ & $<0,001^{*}$ \\
Status gizi (nilai Z-skor) & & & & \\
$\quad$ Z-skor BB/TB(PB) & $-1,00 \pm 0,98$ & $-0,85 \pm 1,05$ & $0,15 \pm 0,79$ & $<0,001^{*}$ \\
Z-skor BB/U & $-1,57 \pm 1,09$ & $-1,49 \pm 1,08$ & $0,08 \pm 0,52$ & $0,003^{*}$ \\
Z-skor TB(PB)/U & $-1,57 \pm 1,43$ & $-1,62 \pm 1,27$ & $-0,05 \pm 0,56$ & 0,052 \\
\hline
\end{tabular}

\footnotetext{
Keterangan : *Uji Paired t-test

BB : berat badan

$\mathrm{TB}(\mathrm{PB})$ : tinggi badan (panjang badan)

$U$ : umur
} 
Tabel 4. Kenaikan berat badan, tinggi/panjang badan, dan daya ungkit multi-mikronutrien fortifikasi

\begin{tabular}{|c|c|c|c|c|}
\hline & Rerata \pm SD & $\delta 1$ & $\delta 2$ & $\begin{array}{c}\text { Daya ungkit } \\
(\%)\end{array}$ \\
\hline \multicolumn{5}{|c|}{ Berat badan $(\mathrm{kg})$} \\
\hline Pre-test & $10,24 \pm 2,25$ & & 0,35 & 57,74 \\
\hline Post-test 1 & $11,19 \pm 2,38$ & 0,95 & & \\
\hline Post-test 2 & $10,84 \pm 2,24$ & 0,60 & & \\
\hline \multicolumn{5}{|c|}{ Tinggi badan $(\mathrm{cm})$} \\
\hline Pre-test & $82,73 \pm 9,34$ & & 0,70 & 24,04 \\
\hline Post-test 1 & $86,33 \pm 8,98$ & 3,61 & & \\
\hline Post-test 2 & $85,63 \pm 8,98$ & 2,91 & & \\
\hline
\end{tabular}

Keterangan: Post test 1: Hasil penelitian

Post test 2: Kenaikan minimal berat badan dan tinggi/ panjang badan, standar antropometri (WHO, 2006) SD : standar deviasi

$\delta$ : delta/perbedaan
Peningkatan berat badan dan tinggi badan atau panjang badan subjek yang terjadi adalah akibat pengaruh dari multi-mikronutrien fortifikasi yang diberikan kepada subjek selama 4 bulan. Kenaikan berat badan setelah diperhitungkan dengan kenaikan berat badan minimal standar adalah sebesar 0,35 kg. Hal ini merupakan daya ungkit multi-mikronutrien sebesar $57,74 \%$. Sedangkan kenaikan tinggi badan atau panjang badan sebanyak $0,7 \mathrm{~cm}$ yang merupakan daya ungkit multi-mikronutrien fortifikasi sebesar 24,04\%.

Ada kecenderungan subjek dengan status gizi kurang (z-skor<-2SD) memiliki pengaruh positif peningkatan berat badan dan tinggi atau panjang badan lebih tinggi dibandingkan dengan subjek dengan status gizi baik atau normal (z-skor $\geq-2 S D$ ) (Tabel 5).

Tabel 5. Berat badan, tinggi/panjang badan, dan status gizi (nilai z-skor) menurut indeks antropometri sebelum dan setelah perlakuan

\begin{tabular}{|c|c|c|c|c|c|}
\hline Variabel & $\mathbf{n}$ & $\begin{array}{c}\text { Awal } \\
\text { (Pre test) }\end{array}$ & $\begin{array}{c}\text { Akhir } \\
\text { (Post test) }\end{array}$ & Perbedaan & $\mathbf{p}$ \\
\hline \multicolumn{6}{|l|}{ Berat badan } \\
\hline \multicolumn{6}{|l|}{$\mathrm{BB} / \mathrm{TB}(\mathrm{PB})$} \\
\hline Z-skor <-2SD & 57 & $8,89 \pm 2,98$ & $9,97 \pm 2,55$ & $1,08 \pm 1,11$ & $<0,001^{*}$ \\
\hline Z-skor $\geq-2 S D$ & 329 & $10,48 \pm 2,21$ & $11,40 \pm 2,29$ & $0,92 \pm 0,62$ & $<0,001^{*}$ \\
\hline \multicolumn{6}{|l|}{$\mathrm{BB} / \mathrm{U}$} \\
\hline Z-skor <-2SD & 136 & $9,10 \pm 1,80$ & $10,10 \pm 2,06$ & $1,00 \pm 3,10$ & $<0,001^{*}$ \\
\hline Z-skor Z-2SD & 250 & $10,87 \pm 2,22$ & $11,78 \pm 2,33$ & $0,91 \pm 0,64$ & $<0,001^{*}$ \\
\hline \multicolumn{6}{|l|}{$\mathrm{TB}(\mathrm{PB}) / \mathrm{U}$} \\
\hline Z-skor <-2SD & 141 & $9,40 \pm 1,84$ & $10,35 \pm 1,93$ & $0,95 \pm 2,70$ & $<0,001^{*}$ \\
\hline Z-skor $\geq-2 S D$ & 245 & $10,73 \pm 2,31$ & $11,67 \pm 2,47$ & $0,94 \pm 0,77$ & $<0,001^{*}$ \\
\hline \multicolumn{6}{|c|}{ Tinggi/panjang badan } \\
\hline \multicolumn{6}{|l|}{$\mathrm{BB} / \mathrm{TB}(\mathrm{PB})$} \\
\hline Z-skor <-2SD & 57 & $81,56 \pm 9,94$ & $84,51 \pm 9,34$ & $2,96 \pm 2,73$ & $<0,001^{*}$ \\
\hline Z-skor $\geq-2 S D$ & 329 & $82,93 \pm 9,24$ & $86,65 \pm 8,88$ & $3,22 \pm 1,32$ & $<0,001^{*}$ \\
\hline \multicolumn{6}{|l|}{$\mathrm{BB} / \mathrm{U}$} \\
\hline Z-skor <-2SD & 136 & $80,08 \pm 8,46$ & $83,65 \pm 8,29$ & $3,48 \pm 13,02$ & $0,002^{*}$ \\
\hline Z-skor $\geq-2 S D$ & 250 & $84,17 \pm 9,50$ & $87,84 \pm 8,99$ & $3,67 \pm 1,73$ & $<0,001^{*}$ \\
\hline \multicolumn{6}{|l|}{$\mathrm{TB}(\mathrm{PB}) / \mathrm{U}$} \\
\hline Z-skor <-2SD & 141 & $79,31 \pm 7,93$ & $83,08 \pm 7,51$ & $3,77 \pm 10,94$ & $<0,001^{*}$ \\
\hline Z-skor $\geq-2 S D$ & 245 & $84,69 \pm 9,54$ & $88,21 \pm 9,23$ & $3,52 \pm 1,73$ & $<0,001^{*}$ \\
\hline \multicolumn{6}{|c|}{ Status gizi (nilai z-skor) } \\
\hline \multicolumn{6}{|l|}{$\mathrm{BB} / \mathrm{TB}(\mathrm{PB})$} \\
\hline Z-skor <-2SD & 57 & $-2,48 \pm 0,41$ & $-1,91 \pm 0,98$ & $0,57 \pm 1,00$ & $<0,001^{*}$ \\
\hline Z-skor $\geq-2 S D$ & 329 & $-0,74 \pm 0,81$ & $-0,67 \pm 0,96$ & $0,07 \pm 0,08$ & 0,076 \\
\hline \multicolumn{6}{|l|}{$\mathrm{BB} / \mathrm{U}$} \\
\hline Z-skor <-2SD & 136 & $-2,64 \pm 0,50$ & $-2,40 \pm 0,69$ & $0,24 \pm 0,88$ & $0,002^{*}$ \\
\hline Z-skor $\geq-2 S D$ & 250 & $-0,98 \pm 0,85$ & $-0,99 \pm 0,91$ & $-0,01 \pm 0,48$ & 0,868 \\
\hline \multicolumn{6}{|l|}{$\mathrm{TB}(\mathrm{PB}) / \mathrm{U}$} \\
\hline Z-skor <-2SD & 141 & $-2,84 \pm 0,67$ & $-2,73 \pm 0,75$ & $0,11 \pm 1,03$ & 0,200 \\
\hline Z-skor z-2SD & 245 & $-0,84 \pm 1,22$ & $-0,99 \pm 1,05$ & $-0,15 \pm 0,61$ & $<0,001^{*}$ \\
\hline
\end{tabular}

Keterangan : *Uji Paired t-test

$$
\begin{array}{ll}
\text { BB } & \text { : berat badan } \\
\text { TB(PB) } & \text { : tinggi badan (panjang badan) } \\
\cup & : \text { umur } \\
\text { SD } & : \text { standar deviasi }
\end{array}
$$


Tabel 6. Berat badan, tinggi/panjang badan, dan status gizi (nilai z-skor) menurut kelompok umur sebelum dan setelah perlakuan

\begin{tabular}{lccccc}
\hline \multicolumn{1}{c}{ Variabel } & $\mathbf{n}$ & $\begin{array}{c}\text { Awal } \\
\text { (Pre test) }\end{array}$ & $\begin{array}{c}\text { Akhir } \\
\text { (Post test) }\end{array}$ & Perbedaan & p \\
\hline $\begin{array}{l}\text { Berat badan } \\
\text { Umur 6-24 bulan }\end{array}$ & 179 & $8,59 \pm 1,45$ & $9,53 \pm 1,62$ & $0,94 \pm 0,60$ & $<0,001^{*}$ \\
$\begin{array}{l}\text { Umur 25-55 bulan } \\
\text { Tinggi/panjang badan }\end{array}$ & 207 & $11,67 \pm 1,78$ & $12,62 \pm 1,96$ & $0,95 \pm 0,80$ & $<0,001^{*}$ \\
$\quad$ Umur 6-24 bulan & 179 & $75,21 \pm 6,05$ & $79,16 \pm 5,63$ & $3,94 \pm 1,78$ & $<0,001^{*}$ \\
$\quad \begin{array}{l}\text { Umur 25-55 bulan } \\
\text { Status gizi (nilai Z-skor) }\end{array}$ & 207 & $89,22 \pm 6,33$ & $92,54 \pm 6,32$ & $3,32 \pm 1,42$ & $<0,001^{*}$ \\
$\quad$ BB/TB(PB) & & & & & \\
$\quad$ Umur 6-24 bulan & 179 & $-1,03 \pm 1,08$ & $-0,90 \pm 1,14$ & $0,12 \pm 0,84$ & $0,049^{*}$ \\
$\quad$ Umur 25-55 bulan & 207 & $-0,96 \pm 0,90$ & $-0,80 \pm 0,97$ & $0,16 \pm 0,74$ & $0,002^{*}$ \\
BB/U & & & & & \\
$\quad$ Umur 6-24 bulan & 179 & $-1,40 \pm 1,17$ & $-1,41 \pm 1,17$ & $-0,01 \pm 0,56$ & 0,798 \\
$\quad$ Umur 25-55 bulan & 207 & $-1,71 \pm 0,99$ & $-1,55 \pm 0,98$ & $0,16 \pm 0,47$ & $<0,001^{*}$ \\
$\quad \begin{array}{l}\text { TB(PB)/U } \\
\text { Umur 6-24 bulan }\end{array}$ & 179 & $-1,27 \pm 1,63$ & $-1,51 \pm 1,39$ & $-0,24 \pm 0,69$ & $<0,001^{*}$ \\
$\quad$ Umur 25-55 bulan & 207 & $-1,83 \pm 1,18$ & $-1,72 \pm 1,15$ & $0,10 \pm 0,37$ & $<0,001^{*}$ \\
\hline
\end{tabular}

Keterangan : *Uji Paired t-test

BB : berat badan

$\mathrm{TB}(\mathrm{PB})$ : tinggi badan (panjang badan)

$U$ : umur

Tabel 7. Asupan zat gizi sebelum dan setelah perlakuan

\begin{tabular}{lcccl}
\hline \multicolumn{1}{c}{ Zat gizi } & Awal (Pre test) & Akhir (Post test) & Perbedaan & \multicolumn{1}{c}{ p } \\
\hline Energi (Kkal) & $754,49 \pm 51,30$ & $854,27 \pm 448,05$ & $99,79 \pm 544,13$ & $<0,001^{*}$ \\
Protein (gr) & $24,61 \pm 16,51$ & $28,70 \pm 19,03$ & $4,09 \pm 21,81$ & $<0,001^{*}$ \\
Vitamin A (mcg) & $441,30 \pm 817,04$ & $477,18 \pm 949,90$ & $35,88 \pm 1166,90$ & 0,546 \\
Vitamin B1 (mg) & $0,24 \pm 0,19$ & $0,27 \pm 0,21$ & $0,03 \pm 0,24$ & $0,027^{*}$ \\
Vitamin B2 (mg) & $0,53 \pm 0,44$ & $0,54 \pm 0,45$ & $0,01 \pm 0,55$ & 0,580 \\
Vitamin B3 (mg) & $3,54 \pm 2,74$ & $4,14 \pm 3,04$ & $0,60 \pm 3,65$ & $0,020^{*}$ \\
Vitamin B6 (mg) & $0,41 \pm 0,27$ & $0,45 \pm 0,27$ & $0,04 \pm 0,02$ & $0,026^{*}$ \\
Vitamin B12(mcg) & $1,59 \pm 3,69$ & $2,02 \pm 0,22$ & $0,43 \pm 0,27$ & 0,113 \\
Vitamin D (mcg) & $2,75 \pm 4,42$ & $3,02 \pm 4,24$ & $0,27 \pm 5,32$ & 0,332 \\
Asam folat (mcg) & $74,98 \pm 80,02$ & $76,19 \pm 76,61$ & $1,21 \pm 101,89$ & 0,816 \\
Vitamin C (mg) & $23,80 \pm 39,38$ & $15,86 \pm 20,74$ & $-8,08 \pm 22,46$ & $<0,001^{*}$ \\
Vitamin E (mg) & $2,05 \pm 2,43$ & $2,23 \pm 2,32$ & $0,18 \pm 3,07$ & 0,261 \\
Fe (mg) & $4,57 \pm 6,29$ & $4,84 \pm 6,50$ & $0,77 \pm 7,54$ & 0,619 \\
Seng (mg) & $3,04 \pm 2,18$ & $3,34 \pm 2,46$ & $0,30 \pm 2,92$ & $0,048^{*}$ \\
\hline
\end{tabular}

Keterangan : *Uji Paired t-test

Ada kecenderungan subjek yang berumur 25-55 bulan memiliki pengaruh positif peningkatan berat badan dan tinggi/panjang badan lebih tinggi dibandingkan dengan subjek yang berumur 6-24 bulan (Tabel 6).

\section{Asupan zat gizi dari makanan balita sebelum dan setelah perlakuan}

Recall konsumsi makanan balita dilakukan untuk mengetahui asupan zat gizi sebelum dan setelah perlakuan. Umumnya terdapat peningkatan beberapa asupan zat gizi absolut pada subjek, namun hanya beberapa asupan zat gizi yang peningkatannya bermakna (Tabel 7).

Sebagian besar rata-rata asupan zat gizi subjek seperti energi, protein, vitamin, dan mineral setelah perlakuan menunjukkan peningkatan kecukupan gizi tertentu berdasarkan angka kecukupan gizi rata-rata yang dianjurkan (AKG). Namun rata-rata peningkatan kecukupan gizi tersebut tidak menunjukkan perbedaan yang bermakna. Untuk dapat mengetahui besarnya ratarata kecukupan gizi subjek, dapat dilihat pada Tabel 8.

Asupan zat gizi subjek yang berasal dari konsumsi makanan keluarga dan mikronutrien intervensi selama 4 bulan perlakuan menunjukkan peningkatan asupan zat gizi secara absolut dan tingkat kecukupan gizi tertentu berdasarkan angka kecukupan gizi rata-rata yang dianjurkan (AKG). Untuk dapat mengetahui besarnya rata-rata peningkatan asupan zat gizi (energi, protein, dan mikronutrien) dan rata-rata tingkat kecukupan gizi subjek, dapat dilihat pada Tabel 9.

Apabila memperhitungkan asupan zat gizi berdasarkan intervensi multi-mikronutrien fortifikasi, maka 
Tabel 8. Tingkat kecukupan gizi berdasarkan AKG sebelum dan setelah perlakuan

\begin{tabular}{lcccc}
\hline \multicolumn{1}{c}{ Zat gizi } & Awal (\% AKG) & Akhir $(\%$ AKG) & Perbedaan & p \\
\hline Energi & $77,40 \pm 49,02$ & $80,47 \pm 43,66$ & $3,07 \pm 61,84$ & 0,329 \\
Protein & $101,90 \pm 73,51$ & $108,00 \pm 74,18$ & $6,10 \pm 101,60$ & 0,239 \\
Vitamin A & $109,71 \pm 203,91$ & $118,025 \pm 237,48$ & $8,32 \pm 314,01$ & 0,603 \\
Vitamin B1 & $49,75 \pm 38,52$ & $52,84 \pm 41,46$ & $3,09 \pm 54,57$ & 0,385 \\
Vitamin B2 & $103,62 \pm 86,70$ & $106,06 \pm 89,29$ & $2,44 \pm 122,10$ & 0,695 \\
Vitamin B3 & $62,18 \pm 53,35$ & $66,25 \pm 49,33$ & $4,07 \pm 71,19$ & 0,262 \\
Vitamin B6 & $89,70 \pm 75,71$ & $86,99 \pm 53,12$ & $-2,70 \pm 92,89$ & 0,568 \\
Vitamin B12 & $192,32 \pm 512,06$ & $219,07 \pm 471,39$ & $26,74 \pm 696,65$ & 0,451 \\
Vitamin D & $54,92 \pm 88,43$ & $60,31 \pm 81,35$ & $5,39 \pm 116,21$ & 0,363 \\
Asam folat & $53,61 \pm 59,35$ & $49,08 \pm 50,77$ & $-4,53 \pm 79,57$ & 0,264 \\
Vitamin C & $59,17 \pm 98,37$ & $39,10 \pm 51,48$ & $-20,07 \pm 109,18$ & 0,000 \\
Vitamin E & $34,40 \pm 40,74$ & $36,26 \pm 37,86$ & $1,86 \pm 54,30$ & 0,500 \\
Fe & $67,94 \pm 142,94$ & $59,43 \pm 80,28$ & $8,50 \pm 167,17$ & 0,319 \\
Seng & $40,28 \pm 42,97$ & $39,66 \pm 29,55$ & $-0,62 \pm 52,01$ & 0,817 \\
\hline
\end{tabular}

Keterangan : *Uji Paired t-test

AKG : angka kecukupan gizi

Tabel 9. Asupan zat gizi sebelum perlakuan dan asupan zat gizi ditambah intervensi multimikronutrien fortifikasi serta rata-rata tingkat kecukupan gizi berdasarkan AKG setelah perlakuan

\begin{tabular}{lcccc}
\hline \multicolumn{1}{c}{ Zat gizi } & $\begin{array}{c}\text { Awal } \\
\text { (Pre test) } \\
(\mathbf{1})\end{array}$ & $\begin{array}{c}\text { Akhir } \\
\text { (Post test) }\end{array}$ & $\begin{array}{c}\text { \% AKG } \\
\text { Akhir/Posttest } \\
(\mathbf{2})\end{array}$ & $\begin{array}{c}\mathbf{p} \\
\mathbf{( 1 ) : ( 2 )}\end{array}$ \\
\hline Energi (Kkal) & $754,484 \pm 51,30$ & $854,27 \pm 448,05$ & $99,79 \pm 544,13$ & $<0,001^{*}$ \\
Protein (gram) & $24,61 \pm 16,51$ & $28,70 \pm 19,03$ & $4,09 \pm 21,81$ & $<0,001^{*}$ \\
Vitamin A (mcg) & $441,30 \pm 817,04$ & $747,57 \pm 950,98$ & $184,37 \pm 237,48$ & $<0,001^{*}$ \\
Vitamin B1 (mg) & $0,24 \pm 0,19$ & $0,61 \pm 0,21$ & $119,19 \pm 41,45$ & $<0,001^{*}$ \\
Vitamin B2 (mg) & $0,53 \pm 0,44$ & $0,89 \pm 0,45$ & $172,41 \pm 89,29$ & $<0,001^{*}$ \\
Vitamin B3 (mg) & $3,54 \pm 2,74$ & $8,31 \pm 3,13$ & $132,60 \pm 49,33$ & $<0,001^{*}$ \\
Vitamin B6 (mg) & $0,41 \pm 0,27$ & $0,79 \pm 0,27$ & $153,34 \pm 53,12$ & $<0,001^{*}$ \\
Vitamin B12(mcg) & $1,59 \pm 3,69$ & $2,64 \pm 4,25$ & $285,42 \pm 471,39$ & $<0,001^{*}$ \\
Vitamin D (mcg) & $2,75 \pm 4,42$ & $6,33 \pm 4,07$ & $126,66 \pm 81,35$ & $<0,001^{*}$ \\
Asam folat (mcg) & $74,98 \pm 80,02$ & $180,46 \pm 78,45$ & $115,43 \pm 50,77$ & $<0,001^{*}$ \\
Vitamin C (mg) & $23,90 \pm 39,38$ & $15,86 \pm 20,74$ & $105,45 \pm 51,48$ & $<0,001^{*}$ \\
Vitamin E (mg) & $2,05 \pm 2,43$ & $6,30 \pm 4,07$ & $102,61 \pm 37,86$ & $<0,001^{*}$ \\
Fe (mg) & $4,57 \pm 6,27$ & $10,24 \pm 6,50$ & $125,79 \pm 80,28$ & $<0,001^{*}$ \\
Seng (mg) & $3,04 \pm 2,18$ & $8,92 \pm 2,52$ & $106,01 \pm 29,55$ & $<0,001^{*}$ \\
\hline
\end{tabular}

Keterangan : *Uji Paired t-test

AKG : angka kecukupan gizi

Tabel 10. Penyakit ISPA dan diare sebelum dan setelah perlakuan

\begin{tabular}{lcccc}
\hline \multicolumn{1}{c}{ Penyakit } & $\begin{array}{c}\text { Awal } \\
\text { (Pre test) }\end{array}$ & $\begin{array}{c}\text { Akhir } \\
\text { (Post test) }\end{array}$ & Perbedaan & p \\
\hline ISPA & & & & \\
Proporsi sakit (\%) & 53,37 & 47,67 & $-5,70$ & $<0,001^{*}$ \\
Insiden (kali) & $0,61 \pm 0,70$ & $0,37 \pm 0,61$ & $-0,24 \pm 0,94$ & $<0,001^{*}$ \\
Lamanya (hari) & $2,51 \pm 4,98$ & $1,67 \pm 2,79$ & $-0,84 \pm 3,82$ & $0,001^{*}$ \\
Diare & 16,58 & 11,14 & $-5,44$ & $<0,001^{*}$ \\
Proporsi sakit (\%) & $0,31 \pm 0,91$ & $0,12 \pm 0,36$ & $-0,19 \pm 0,96$ & $<0,001^{*}$ \\
Insiden (kali) & $0,44 \pm 1,22$ & $0,40 \pm 1,34$ & $-0,04 \pm 1,73$ & 0,702 \\
Lamanya (hari) & & & & \\
\hline
\end{tabular}

Keterangan: * Uji Paired t-test

ISPA : infeksi saluran pernafasan akut

asupan zat gizi menunjukkan peningkatan yang bermakna $(p<0,05)$ untuk semua zat gizi mulai dari energi, protein, dan mikronutrien. Demikian pula dengan angka kecukupan zat gizi rata-rata yang dianjurkan (AKG), semuanya menunjukkan kecukupan gizi di atas $100 \%$.

\section{Penyakit infeksi (ISPA dan diare) sebelum dan setelah perlakuan}

Pertumbuhan subjek dipengaruhi oleh penyakit infeksi seperti ISPA dan diare. Terjadi penurunan yang bermakna terhadap rata-rata proporsi sakit, insiden, dan 
lamanya ISPA serta proporsi sakit dan insiden diare pada subjek setelah perlakuan (Tabel 10).

\section{BAHASAN}

\section{Pemberian multi-mikronutrien fortifikasi}

Pemberian multi-mikronutrien fortifikasi dilakukan kepada subjek selama 4 bulan dengan dosis satu sachet per hari. Pelaksanaan pemberian dan pemantauan asupan multi-mikronutrien dilakukan seminggu sekali. Berdasarkan hasil pemantauan yang dilakukan sampai akhir penelitian, rata-rata asupan multi-mikronutrien fortifikasi subjek sebanyak 80 sachet atau $66,35 \%$. Proporsi asupan multimikronutrien fortifikasi menurut jenis kelamin, subjek laki-laki balita lebih banyak 1,45\% dibandingkan asupan multi-mikronutrien fortifikasi subjek perempuan.

Berdasarkan umur, subjek yang berumur 6-24 bulan, asupan multi-mikronutrien fortifikasi $0,59 \%$ lebih banyak dibandingkan dengan subjek yang berumur 25-55 bulan. Asupan multi-mikronutrien fortifikasi subjek dengan status gizi kurang (z-skor <-2SD), proporsinya lebih besar dibandingkan dengan subjek dengan status gizi baik (z-skor $\geq-2 S D$ ). Hal ini menunjukkan bahwa telah terjadi variasi asupan rata-rata multi-mikronutrien fortifikasi pada subjek.

\section{Berat badan dan tinggi badan atau panjang badan}

Berdasarkan hasil pengukuran antropometri, setelah dilakukan intervensi berupa pemberian multi-mikronutrien fortifikasi, terjadi perubahan ukuran fisik subjek berupa pertambahan rata-rata berat badan sebesar 0,95 $\pm 0,71$ $\mathrm{kg}$ dan peningkatan rata-rata tinggi badan atau panjang badan sebanyak $3,61 \pm 1,63 \mathrm{~cm}$. Rata-rata pertambahan berat badan dan peningkatan panjang badan atau tinggi badan menurut statistik adalah bermakna $(p<0,05)$.

Kenaikan berat badan dan tinggi badan merupakan besarnya daya ungkit dari mikronutrien yang diberikan kepada subjek selama 4 bulan. Bila dibandingkan dengan kenaikan berat badan dan tinggi badan minimal tanpa intervensi menurut kelompok umur yang sama dengan subjek penelitian, maka selisih kenaikan berat badan dan tinggi/ panjang badan masing-masing adalah sebesar $0,60 \mathrm{~kg}$ dan $2,91 \mathrm{~cm}$. Berdasarkan selisih kenaikan berat badan dan tinggi/ panjang badan, maka besar daya ungkit multi-mikronutrien fortifikasi terhadap pertumbuhan adalah $57,74 \%$ untuk berat badan dan $24,04 \%$ untuk tinggi/panjang badan.

Peningkatan berat badan dan tinggi/panjang badan yang bermakna $(p<0,05)$ terjadi baik pada kelompok umur subjek 6-24 bulan maupun pada kelompok umur subjek 2555 bulan. Namun ada kecenderungan pertambahan berat badan subjek lebih besar terjadi pada kelompok umur 2555 bulan dan peningkatan tinggi/panjang badan cenderung lebih besar terjadi pada kelompok umur 6-24 bulan. Hal ini karena untuk peningkatan tinggi badan diperlukan asupan zat gizi makro (makronutrien) seperti energi dan protein yang cukup. Subjek yang berumur 6-24 bulan masih mendapat asupan zat gizi (energi dan protein) yang cukup dari ASI, sedangkan subjek yang berumur 25-55 bulan sudah tidak menyusui dan asupan makronutrien dari makanan keluarga tidak mencukupi, mengingat makanan keluarga miskin rendah dalam kualitas dan kuantitas.

Demikian juga dengan peningkatan berat badan dan tinggi/panjang badan secara bermakna terjadi baik untuk subjek dengan kategori gizi kurang (z-skor <-2SD), maupun subjek dengan kategori gizi baik ( $z$-skor $\geq-2 S D$ ) berdasarkan indeks $\mathrm{BB} / \mathrm{TB}(\mathrm{PB}), \mathrm{BB} / \mathrm{U}$, dan $\mathrm{TB}(\mathrm{PB}) / \mathrm{U}$. Kecenderungan peningkatan berat badan lebih besar terjadi pada subjek dengan kategori gizi kurang (z-skor $<-2 S D$ ) dibandingkan dengan subjek yang berkategori gizi baik (z-skor $\geq-2 S D$ ). Namun peningkatan tinggi/panjang badan cenderung lebih besar terjadi pada subjek dengan kategori gizi baik (z-skor $\geq-2 S D$ ) yang memiliki energi dan protein yang cukup.

Hasil penelitian ini sejalan dengan hasil penelitian yang dilakukan di Jawa Tengah tentang suplementasi vitamin A yang dilakukan pada anak usia 6-48 bulan bahwa suplementasi vitamin A dapat meningkatkan pertumbuhan linear (8). Penelitian lain di Vietnam menunjukkan bahwa suplementasi mikronutrien selama 3 bulan terhadap anak usia 6-24 bulan dapat meningkatkan pertambahan berat badan sebanyak 1,4 $\pm 0,7 \mathrm{~kg}$ dan peningkatan tinggi badan pada subjek yang pendek (9). Penelitian tentang efikasi suplemen multi-mikronutrien pada bayi di Indonesia, Peru, Afrika Selatan, dan Vietnam juga menunjukkan bahwa pemberian multi-mikronutrien selama 6 bulan dapat meningkatkan berat badan pada kelompok suplementasi multi-mikronutrien harian sebanyak 0,21 $\pm 0,09 \mathrm{~kg}$ (10). Penelitian serupa yang dilakukan di Meksiko menunjukkan bahwa pemberian multi-mikronutrien pada anak usia 8-14 bulan selama 12 bulan dapat meningkatkan tinggi badan sebanyak $8,3 \mathrm{~mm}$ (11).

Bertambahnya ukuran fisik adalah sebagai akibat bertambahnya jumlah dan ukuran sel serta jaringan yang dapat diukur dalam kilogram untuk berat badan dan centimeter untuk panjang badan atau tinggi badan. Percepatan pertumbuhan maksimum terjadi pada akhir masa janin dan menurun sampai melewati masa bayi. Selain genetika, pertumbuhan dipengaruhi oleh faktor lingkungan postnatal yang juga dipengaruhi oleh lingkungan yang membentuknya antara lain asupan zat gizi baik makronutrien maupun mikronutrien (12).

Penambahan berat badan dan peningkatan panjang atau tinggi badan merupakan gambaran dari adanya keseimbangan antara asupan dan kebutuhan gizi anak yang sedang dalam proses pertumbuhan (3). Asupan zat gizi yang kurang atau terbatas akan mengganggu konsentrasi insulin-like growth factor, yaitu dapat menghambat laju pertumbuhan fisik pada balita (13). Selanjutnya dikatakan bahwa terjadinya peningkatan 
berat badan dan tinggi badan atau panjang badan erat hubungannya dengan terpenuhinya kecukupan vitamin A, B1, B2, B12, C, E, tembaga, besi, dan yodium yang mempunyai fungsi tidak langsung, dan zat gizi yang berhubungan langsung dengan terjadinya peningkatan berat badan dan tinggi badan adalah energi, nitrogen, asam amino esensial, asam lemak esensial, potassium, fosfor, dan zink (14).

\section{Status gizi (nilai z-skor) menurut indeks antropometri $B B / T B(P B), B B / U$, dan TB(PB)/U}

Peningkatan status gizi subjek usia 0-55 bulan berdasarkan perubahan nilai z-skor menurut indeks antropometri $\mathrm{BB} / \mathrm{TB}(\mathrm{PB})$ dan $\mathrm{BB} / \mathrm{U}$ terjadi secara bermakna setelah subjek mendapat perlakuan. Peningkatan status gizi (nilai z-skor) menurut indeks BB/TB(PB) terjadi secara bermakna untuk subjek umur 6-24 bulan dan subjek umur $25-55$ bulan. Sedangkan menurut indeks BB/U dan $\mathrm{TB}(\mathrm{PB}) / \mathrm{U}$, peningkatan status gizi (nilai z-skor) terjadi pada subjek umur 25-55 bulan. Hal ini karena subjek dengan riwayat kurang gizi kronis memerlukan asupan makronutrien dan mikronutrien yang optimal.

Ada kecenderungan peningkatan positif status gizi (nilai z-skor) lebih baik terjadi pada subjek yang berumur 25-55 bulan dibandingkan dengan subjek yang berumur 6-24 bulan. Menurut kategori status gizi dengan z-skor $<-2 S D$ (gizi kurang) dan $\geq-2 S D$ (gizi baik atau normal), peningkatan status gizi (nilai z-skor) secara bermakna terjadi pada subjek dengan kategori z-skor <-2SD menurut indeks $\mathrm{BB} / \mathrm{TB}(\mathrm{PB})$ dan $\mathrm{BB} / \mathrm{U}$, sedangkan subjek dengan kategori z-skor $\geq-2 S D$ peningkatannya tidak bermakna.

Ada kecenderungan peningkatan positif status gizi (nilai z-skor) terjadi pada subjek dengan status gizi z-skor $<-2 S D$ dibandingkan dengan subjek yang berstatus gizi z-skor $\geq-2 S D$. Peningkatan nilai z-skor menurut indeks BB/ $\mathrm{TB}(\mathrm{PB})$ dan $\mathrm{BB} / \mathrm{U}$ lebih besar atau lebih tinggi dibandingkan dengan peningkatan nilai z-skor menurut indeks $T B(P B) / U$. Demikian halnya peningkatan nilai z-skor menurut indeks $\mathrm{BB} / \mathrm{U}$ adalah lebih tinggi dibandingkan menurut indeks $\mathrm{TB}(\mathrm{PB}) / \mathrm{U}$, bahkan terjadi kemerosotan status gizi (nilai z-skor) untuk indeks TB(PB)/U. Hal ini disebabkan peningkatan tinggi/panjang badan belum sesuai dengan penambahan umur subjek. Keadaan ini menunjukkan bahwa riwayat keadaan gizi subjek cenderung ke arah indikasi kurang gizi kronis.

Keadaan tersebut menggambarkan bahwa balita dengan riwayat kurang gizi kronis yang mendapatkan intervensi, peningkatan pertumbuhannya atau peningkatan status gizi (nilai z-skor) akan cenderung sangat rendah atau bahkan mengalami kemerosotan untuk indeks antropometri $\mathrm{TB}(\mathrm{PB}) / \mathrm{U}$. Pada penelitian ini pemberian multi-mikronutrien fortifikasi dapat meningkatkan berat badan dan tinggi badan atau panjang badan, namun belum mampu mengejar pertumbuhan yang optimal sehingga peningkatan pertumbuhan untuk indeks TB(PB)/U belum membaik. Penelitian yang dilakukan terhadap anak-anak Afrika Selatan menunjukkan bahwa suplementasi multimikronutrien dapat meningkatkan status mikronutrien tetapi belum mampu mencegah merosotnya pertumbuhan (15). Dikemukakan pula bahwa meskipun anak-anak mendapat mikronutrien dalam jumlah yang cukup tetapi asupan energi dan proteinnya berkualitas rendah, hal ini akan menjadi faktor pembatas terhadap pertumbuhan yang optimal (16).

Asupan zat gizi dari makanan berkualitas sangat penting untuk pertumbuhan, karena makanan yang rendah nilai gizinya dapat berpengaruh dan menghambat proses pertumbuhan. Keadaan ini umumnya terjadi pada masyarakat miskin yang hanya mampu menyediakan makanan dengan kualitas rendah untuk diberikan pada keluarganya (17). Sesuai hasil penelitian bahwa keluarga subjek yang merupakan keluarga miskin, $64,61 \%$ dari total pengeluaran keluarga adalah pengeluaram untuk makan. Hal ini menunjukkan bahwa terdapat kesulitan bagi keluarga untuk dapat menyediakan makanan yang berkualitas, karena rendahnya daya beli keluarga. Untuk itu dapat disimpulkan bahwa pertumbuhan balita atau peningkatan nilai z-skor akan terjadi secara meyeluruh berdasarkan indeks $B B / T B(P B), B B / U$, dan $T B(P B) / U$, apabila adanya asupan gizi secara komprehensif yaitu asupan makronutrien dan mikronutrien secara optimal.

\section{Asupan zat gizi dan asupan multi-mikronutrien fortifikasi}

Subjek setelah diberikan perlakuan berupa pemberian multi-mikronutrien fortifikasi mengalami peningkatan asupan zat gizi secara absolut. Ada beberapa asupan zat gizi yang mengalami peningkatan yang bermakna dibandingkan sebelum perlakuan. Peningkatan asupan zat gizi yang bermakna tersebut adalah energi sebesar 99,79 $\pm 544,13 \mathrm{Kal}$; protein sebanyak 4,09 $\pm 21,81 \mathrm{~g}$; vitamin B1 sebanyak $0,03 \pm 0,24 \mathrm{mg}$; vitamin $B 3$ sebanyak $0,06 \pm 3,65$ $\mathrm{mg}$; vitamin B6 sebanyak 0,04 $\pm 0,02 \mathrm{mg}$; dan seng (zink) sebanyak 0,30 $\pm 2,92 \mathrm{mg}$. Dibandingkan dengan asupan zat gizi subjek yang memperhitungkan AKG, secara prosentase umumnya asupan zat gizi subjek mengalami peningkatan rata-rata kecukupan zat gizi setelah mendapat perlakuan, namun peningkatan tersebut secara statistik tidak bermakna.

Jumlah asupan zat gizi seperti energi, protein, dan mikronutrien setelah perlakuan mengalami peningkatan. Asupan energi dan protein mengalami peningkatan yang bermakna $(p<0,05)$, demikian pula dengan asupan mikronutrien, hal ini dipengaruhi adanya asupan mikronutrien intervensi. Dengan adanya asupan mikronutrien intervensi, maka tingkat kecukupan mikronutrien subjek lebih dari 100\% AKG, dengan rincian bahwa asupan mikronutrien subjek yang berasal dari makanan keluarga rata-rata 
kurang lebih $40 \%$ dan asupan mikronutrien intervensi ratarata $66,36 \%$. Demikian juga kecukupan protein mencapai $108 \%$ AKG, namun untuk energi tingkat kecukupannya baru mencapai $80 \%$ AKG.

Terkait dengan pertumbuhan, belum terjadinya peningkatan nilai z-skor subjek menurut $\mathrm{TB}(\mathrm{PB}) / \mathrm{U}$ setelah 4 bulan diintervensi disebabkan oleh peningkatan asupan mikronutrien yang tidak diikuti dengan peningkatan asupan zat gizi makro (makronutrien) dari makanan keluarga secara optimal. Keadaan ini terjadi mengingat keluarga miskin mempunyai keterbatasan untuk menyediakan makanan yang berkualitas dalam jumlah maupun mutu bagi balitanya, sehingga belum dapat memberikan dampak optimal pada perubahan pertumbuhan. Pertumbuhan linear, pertumbuhan ponderal, berat badan dan tinggi badan akan tercapai bila asupan energi, makronutrien, dan mikronutrien sudah terpenuhi sesuai kebutuhan (18).

Tidak berhasilnya intervensi berupa suplementasi untuk dapat memberikan dampak terhadap pertumbuhan, adalah sangat mungkin akibat dari asupan energi yang tidak adekuat dari makanan keluarga (15). Keadaan ini mungkin terjadi karena subjek penelitian ini berasal dari keluarga miskin yang memiliki keterbatasan dalam daya beli pangan berkualitas untuk diberikan pada anggota keluarganya termasuk balita.

\section{Penyakit infeksi (ISPA dan diare) dan tingkat asupan multi-mikronutrien fortifikasi}

Proporsi subjek yang sakit ISPA dan diare menunjukkan perbedaan penurunan yang bermakna setelah mendapat perlakuan berupa pemberian multi-mikronutrien fortifikasi. Demikian halnya insiden rate atau rata-rata kejadian ISPA dan diare menunjukkan penurunan yang bermakna. Ratarata penurunan proporsi sakit ISPA sebanyak $5,70 \%$ dan proporsi sakit diare sebanyak $5,44 \%$. Rata-rata penurunan insiden ISPA sebanyak 0,24 $\pm 0,94$ episode dan insiden diare sebanyak 0,19 $\pm 0,96$ episode.

Penurunan rata-rata lamanya (jumlah hari) ISPA dan diare juga menunjukkan penurunan. Penurunan rata-rata lamanya ISPA yang bermakna sebanyak 0,84 $\pm 3,82$ hari. Berbeda dengan penurunan lamanya diare yang tidak bermakna yaitu sebesar $0,04 \pm 1,73$ hari. Hasil penelitian lain juga menunjukkan bahwa suplementasi vitamin $A$ dan zink tidak menurunkan lamanya diare secara bermakna (19).

Terjadinya penurunan proporsi sakit, insiden, dan lamanya ISPA yang bermakna dan penurunan proporsi sakit dan insiden diare yang bermakna, serta penurunan lamanya diare walaupun tidak bermakna, erat kaitannya dengan asupan mikronutrien intervensi terutama zink. Keadaan tersebut menunjukkan bahwa terdapat pengaruh positif asupan multi-mikronutrien fortifikasi terhadap penurunan penyakit ISPA dan diare (proporsi sakit, insiden, dan lamanya).
Sesuai dengan penelitian lain yang menunjukkan bahwa zink, zat besi ( $\mathrm{Fe}$ ), dan vitamin A berpengaruh terhadap penurunan infeksi dan meningkatkan nafsu makan (20). Vitamin A, vitamin C, dan Fe telah banyak dilaporkan secara jelas dapat mempercepat penyembuhan ISPA (21). Faktor risiko terjadinya ISPA berhubungan secara bermakna dengan kepadatan hunian dan asma pada balita serta mempunyai efek positif terhadap lamanya ISPA (22). Ditambahkan pula bahwa terpenuhinya kebutuhan vitamin A, B, dan C akan dapat meningkatkan imunitas sehingga dapat menurunkan infeksi, meningkatkan nafsu makan, serta berperan dalam meningkatkan absorbsi zat gizi lainnya seperti zat besi (23).

Prevalensi jenis penyakit yang berkaitan dengan masalah gizi belum tercatat secara lengkap, tetapi penyakit infeksi seperti ISPA dan diare merupakan faktor dominan yang paling berpengaruh (24). Diare yang dialami anak akan berdampak pada terjadinya gangguan gizi dan kegagalan pertumbuhan bahkan setiap serangan diare menyebabkan kehilangan berat badan yang menetap karena terganggunya keseimbangan asam basa (25). Anak yang menderita penyakit infeksi akan memberikan dampak pada penurunan nafsu makan, penurunan daya serap gizi, kebutuhan metabolik meningkat, bahkan kehilangan zat-zat gizi sehingga mempengaruhi proses pertumbuhan (18).

\section{KESIMPULAN DAN SARAN}

Hasil penelitian menunjukkan bahwa rata-rata asupan multi-mikronutrien fortifikasi terhadap keluarga miskin 0-59 bulan sebanyak 80 sachet $(66,35 \%)$. Ada pengaruh yang bermakna asupan multi-mikronutrien fortifikasi terhadap peningkatan berat badan, tinggi/ panjang badan, status gizi (nilai z-skor) indeks $B B / T B(P B)$ dan $B B / U$, serta penurunan proporsi sakit, insiden dan lamanya ISPA, penurunan proporsi sakit dan insiden diare pada balita keluarga miskin usia 6-59 bulan setelah diberikan multi-mikronutrien fortifikasi.

Ada kecenderungan pengaruh positif pemberian multi-mikronutrien fortifikasi lebih besar pada balita keluarga miskin usia 25-59 bulan dan balita dengan status gizi kurang (z-skor <-2SD). Peningkatan ukuran antropometri subjek belum dapat mengejar pertumbuhan optimal untuk memperbaiki status gizi kronis (indeks $\mathrm{TB}(\mathrm{PB}) / \mathrm{U}$ ) yang terjadi, akan tetapi peningkatan tersebut sudah menunjukkan bahwa pemberian multi-mikronutrien dapat memberikan pengaruh yang positif terhadap perbaikan pertumbuhan balita.

Pemberian multi-mikronutrien fortifikasi lebih baik bila diberikan pada balita keluarga miskin usia 25-59 bulan dengan status gizi kurang (z-skor <-2SD). Pemberian multimikronutrien fortifikasi pada balita kelurga miskin dengan riwayat kurang gizi kronis, sebaiknya diikuti dengan upaya peningkatan asupan zat gizi (energi dan protein) 
yang adekuat (berkualitas dalam jumlah dan mutu) untuk pertumbuhan balita yang optimal.

\section{UCAPAN TERIMA KASIH}

Penelitian ini terlaksana atas dukungan dari Pemerintah Pusat melalui Departemen Kesehatan Republik Indonesia. Bersama ini kami mengucapkan terima kasih kepada Direktur Jenderal Bina Kesehatan Masyarakat, Kepala Pusat Perencanaan dan Pendayagunaan Sumberdaya Manusia Kesehatan, Direktur Bina Gizi Masyarakat, Ketua Kelompok Gizi Masyarakat, Pusat Penelitian dan Pengembangan Gizi dan Makanan, Kepala Suku Dinas Kesehatan Kota Jakarta Utara, Kepala Puskesmas Kecamatan dan Kelurahan wilayah Kecamatan Cilincing, Koja, dan Penjaringan, dan ibu-ibu kader posyandu pada lokasi penelitian serta seluruh responden penelitian yang telah membantu dan mendukung terlaksananya penelitian ini sampai selesai.

\section{RUJUKAN}

1. Untoro R. Kebijakan dan program gizi anak di Indonesia. Dalam: Prosiding Inovasi Pangan dan Gizi untuk Optimalisasi Tumbuh Kembang Anak. Jakarta: ILS, Depkes, IPB \& American Soybean Association; 2004.

2. Departemen Kesehatan \& Biro Pusat Statistis. Integrasi indikator gizi dalam Susenas. Jakarta: Departemen Kesehatan \& Biro Pusat Statistis; 2005.

3. Departemen Kesehatan. Pemantauan pertumbuhan balita. Jakarta: Depkes; 2003.

4. Badan Perencanaan Pembangunan Nasional. Rencana aksi nasional pangan dan gizi 2006-2010. Jakarta: BPPN; 2007.

5. Untoro R. Masalah gizi mikro di Indonesia dan potensi penanggulangannya. Dalam: Prosiding Fortifikasi Tepung Terigu dan Minyak Goreng. Jakarta: Pusat Studi Kebijakan Pangan dan Gizi, Komisi Fortifikasi Nasional \& ADB-Manila dan Keystone Centre-USA; 2002.

6. Lemeshow S, Hosmer Jr.DW, Klar J, Lwanga SK. Besar subjek dalam penelitian kesehatan. Pramono D. 1997 (Alih bahasa). Yogyakarta: Gadjah Mada University Press; 1997.

7. Jahari $A B$, Jus'at I. Review: antropometri secara nasional dan internasional. Dalam: Prosiding Diskusi Pakar Bidang Gizi tentang ASI, MP-ASI, Antropometri dan BBLR. Cipanas: PERSAGI, LIPI, dan UNICEF; 2000.

8. Hadi H, Stoltzfus RJ, Dibley MJ, Moulton LH, West KP, Kjolhede CL, Sadjimin T. Vitamin A supplementation selectively improves the linear growth of Indonesia preschool children : from a randomized controlled trial. Am J Clin Nutr 2000; 71(2): 507-13.
9. Thu BD, Schultink W, Dillon D, Gross R, Leswara $\mathrm{ND}, \mathrm{Khoi} \mathrm{HH}$. Effect of daily and weekly micronutrient supplementation in micronutrient defficiency and growth in young Vietnamese children. Am J Clin Nutr 1999; 69(1): 80-6.

10. Smuts CM, Lombard CJ, Benade AJS, Dhansay MA, Berger J, Hop LT, de Romana GL, Untoro J, Karyadi E, Enhardt J, Gross R. Efficacy of a foodlet-based multiple micronutrient supplement for preventing growth faltering, anemia and micronutrient deficiency of infants: the four country IRIS trial pooled data analysis. J Nutr 2005; 135(3): 631S-8S.

11. Rivera JA, Cossio TG, Flores M, Romero M, Rivera M, Rojo MMT, Rosado JL, Brown KH. Multiple micronutrient supplemen increase the growth of Mexican infans. Am J Clin Nutr 2001; 74(5): 657-63.

12. Amiruddin R.Tumbuh kembang anak [serial online] 2007 [cited $2008 \mathrm{Jul} 6$ ]. Available from: http:// ridwanamiruddin.wordpress.com/2007/05/05/tumbuhkembang-anak.

13. Estivariz CF, Ziegler TR. Nutrition and the insulin-like growth factor system. Endocrine 1997; 7(1): 65-71.

14. Golden BE, Golden MHN. Relationship among diitary quality, children's appetites, growth stunting, and efficiency of growth in poor populations. Food Nutr Bull 1991; 3: 105-9.

15. Smuts CM, Dhansay MA, Faber M, Van Stuijvenberg ME, Swanevelder S, Gross R, Benede AJS. Efficacy of a multiple micronutrient supplementation for improving anemia micronutrient status, and growth in South African Infants. J Nutr 2005; 135(3): 653S-9S.

16. Bhandari N, Bahl R, Taneja S. Effect of micronutrient supplementation on linear growth of children. British Journal of Nutrition 2001; 85(Suppl 2): S131-7.

17. Hardinsyah. Analisis kebutuhan konsumsi pangan. Bogor: Pusat Studi Kebijakan Pangan dan Gizi, Institut Pertanian Bogor, Badan Ketahanan Pangan Departemen Pertanian; 2002.

18. Riyadi H. Buku ajar metode penilaian status gizi secara antropometri. Bogor: Gizi Masyarakat dan Sumber Daya Keluarga, IPB; 2001.

19. Long KZ, Rosado JL, Montoya Y, Solano ML, Hertzmark E, Dupont HL, Santos JI. Effect of vitamin A and zink supplementation on gastrointestinal parasitic infections among Mexican children. Pediatrics 2007; 120(4): 846-55.

20. Rivera JA, Hotz C, Cossio TZ, Neufald L, Guirerra AG. The effect of micronutrient deficiencies in child growth: a review of results from community-based supplementation trials. J Nutr 2003; 133(11): 4010S-20S.

21. Widajanti L, Hartini S, Kartasurya MI, Kartini A, Kusbiyantoro, Pradigdo FS, Widjasena B, Nurhayati F. Suplementasi zat besi, vitamin $A$ dan vitamin $C$ untuk mempercepat penyembuhan infeksi saluran pernapasan 
akut (ISPA) bagian bawah. Dalam: Prosiding Widyakarya Nasional Pangan dan Gizi VIII. Jakarta: Lembaga IImu Pengetahuan Indonesia; 2004.

22. Kartasasmita CB. Morbiditas dan faktor risiko infeksi saluran pernapasan akut (ISPA) pada Balita di Cikutra, suatu daerah urban di Kotamadya Bandung. Majalah Kedokteran Bandung 1993; 25(4): 135-42.

23. Muhilal, Sulaeman A. Penentuan kebutuhan gizi dan kesepakatan harmonisasi di Asia Tenggara. Dalam:
Prosidng Widyakarya Nasional Pangan dan Gizi VIII. Jakarta: Lembaga Ilmu Pengetahuan Indonesia; 2004.

24. Atmarita, Falah TS. Analisis situasi gizi dan kesehatan masyarakat. Dalam: Prosiding Widyakarya Nasional Pangan dan Gizi VIII. Jakarta: Lembaga IImu Pengetahuan Indonesia; 2004.

25. Subijanto MS, Ranuh R, Djupri L, Soeparto P. Manajemen diare pada bayi dan anak. Bulletin IImu Kesehatan Anak 2003; 3(11): 508-18. 